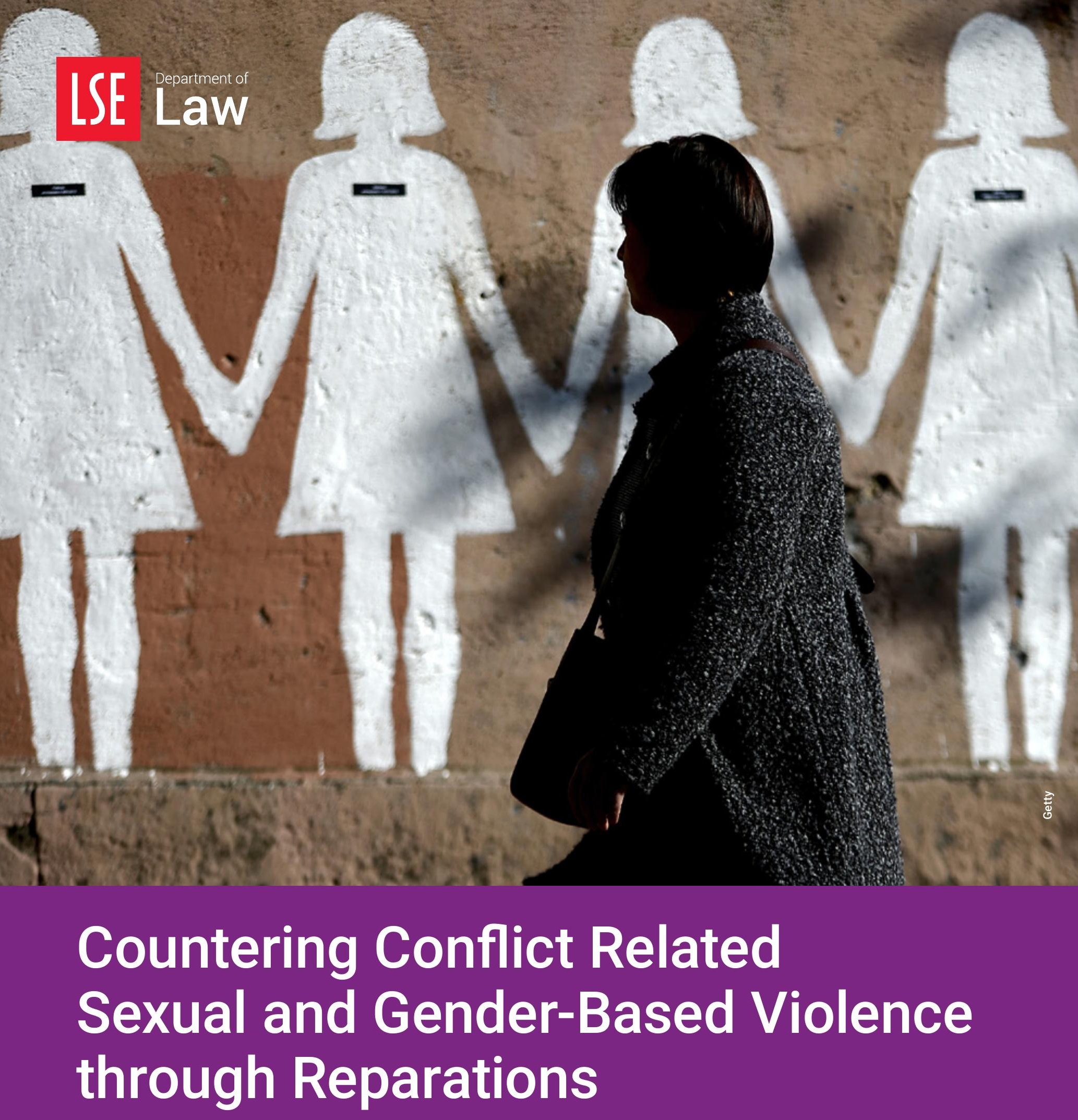

Countering Conflict Related Sexual and Gender-Based Violence through Reparations

Sheri A Labenski

London School of Economics and Political Science 


\section{Countering Conflict Related Sexual and Gender-Based Violence through Reparations}

\section{Where are the survivors?}

Across the world, women and girls continue to experience a variety of gendered harms rooted in sex and gender-based discrimination. Discriminatory practices are typically fuelled by and exacerbated in armed conflict leading to the amplification of gendered harms including, most notably, sexual and gender-based violence or conflict related sexual violence (CRSV). CRSV includes such acts as rape, trafficking, sexual enslavement, forced pregnancy, forced abortion, forced marriage, forced prostitution, forced sterilisation and forced nudity. This issue is important for all survivors of CRSV, who are targeted for their sexuality or gender, but this policy brief is addressed to women survivors.

Preventing and responding to CRSV has dominated the international agenda for at least the last two decades and enormous efforts have gone into developing the normative and institutional architecture to hold individuals criminally accountable exemplified by the establishment of the International Criminal Court (ICC). Tackling impunity has also molded policy priorities including, for example, the UK government's Preventing Sexual Violence in Conflict Initiative (PSVI). However, for the vast majority of women and girls who have experienced CRSV, these advances have not delivered justice whether in the form of accountability or gender sensitive reparations; nor have they led to change.

Against this backdrop, and in response to civil society calls for the need to adopt a survivor-centric approach, the UN Security Council adopted Resolution 2467 (2019) urging States to adopt a survivor-centered approach in preventing and responding to CRSV. The Resolution, as part of its agenda on women, peace and security, also encouraged States to "give due consideration to the establishment of a survivors' fund". In October 2019, a multi-stakeholder Global Survivors Fund (GSF) for survivors of CRSV was launched at the UN by Nobel Peace Prize winners Denis Mukwege and Nadia Murad, who had been campaigning for the creation of an international reparations fund.

\section{What is the Global Survivors Fund?}

Although still in its infancy, the GSF aims to secure meaningful justice for victims through the creation of a complementary mechanism to overcome the deficiencies of existing national and international justice mechanisms and to ensure that the specific needs of survivors are met. According to Mukwege and Murad, "programs will be initiated at the local level to ensure they are survivor centric and contextualised for the local setting and address the specific needs of individual survivors or groups of survivors". The GSF has the potential to provide those most in need with the essential and particular support that is currently beyond their grasp.

Importantly, and notwithstanding repeated references to reparations, the GSF does not claim to be a 'reparations' fund as such. Rather, the main functions of the GSF will be: to allocate financial resources for programmes; provide technical advice; collect and disseminate good practice; and "advocate for duty-bearers to assume responsibility" in order to "improve access to reparations and other forms of redress". The GSF thus attempts to bridge the existing gap between legal obligations and the often dire record of States to live up to those obligations in practice. It is a fund that seeks not only to provide practical and specific support to survivors, but one that aims to promote law compliance by States.

The GSF is a welcome development. However, care must be taken not to confuse or equate the allocation of resources from the GSF with the right of victims to reparations under international human rights law, or indeed pursuant to the Rome Statute of the International Criminal Court (ICC). The GSF is a humanitarian assistance scheme, while the right to reparation derives from the breach of a legal obligation that is owed by the wrongdoer to the victim. Accordingly, the ICC has the authority to issue an order for reparation against a convicted person for their part in committing the crime. Likewise, human rights law requires the State to provide reparations for a wrong attributable to it, or for failing to meet its due diligence obligation in respect of third party wrongdoing. As the proponents of the GSF expressly note, "the support provided by the Fund is not intended to release states or other groups from their own responsibility to provide reparations". 


\section{What does international human rights law say about reparations?}

The right to reparation is founded on the right to an effective remedy as set forth in international and regional human rights treaties. The obligation on States to ensure that victims have effective access to reparations is also found in regional treaties concerned with preventing and combatting violence against women, whether perpetrated in peace time or in armed conflict. States have the obligation to comply with international and regional human rights law, i.e. human rights treaties to which they are parties and customary international law including jus cogens norms.

The 2005 UN Basic Principles and Guidelines on the Right to a Remedy and Reparation for Victims of Gross Violations of International Human Rights Law and Serious Violations of International Humanitarian Law [Basic Principles], together with international jurisprudence, have clarified the disparate and sometimes vague language around reparations found in human rights treaties. The Basic Principles affirm that victims have "[t] he right to adequate, effective and prompt reparation for the harm suffered" and elaborate on the different forms of reparation recognised in human rights law including restitution, compensation, rehabilitation, satisfaction and guarantees of non-repetition. The prosecution of perpetrators and access to justice mechanisms for survivors are types of reparation as methods of satisfaction. Truth telling, as well as the construction of memorials that recognise the losses suffered by the population, are alternative ways for individuals and groups to gain recognition for the harms they have suffered. In short, reparations can be material or symbolic, individual or collective. Irrespective of form, reparations provide recognition to victims as rights holders.

The right to reparation must be recognised as an additional right for survivors of human rights violations over and above the human rights entitlements of the entire population. This is especially true of economic and social rights, for instance access to healthcare services or education facilities, which may overlap with forms of reparation. The provision of general welfare services may not be treated as a form of reparation and must not be substituted for them.
The Basic Principles were adopted in a time when States were increasingly turning to administrative reparation schemes as transitional justice mechanisms in the aftermath of conflict and widespread political violence. Administrative reparation schemes are commonly introduced by States as part of transitional justice programmes to respond more effectively to largescale violations of international law. The benefits of such programmes are that they can obviate common barriers confronted by victims in accessing formal justice processes including the high costs of litigation, satisfying judicial evidential standards, and the risk of re-traumatisation and secondary victimisation that come with judicial processes and cross-examination. Since many of these barriers disproportionately exclude women and girls from accessing justice, administrative reparations can function as a vital life-line for them.

\section{What's gender got to do with it?}

In practice, however, most administrative programmes have been concerned with reparation for violations of political and civil rights (for example arbitrary detention, summary execution, forced disappearance) which disproportionately affect men rather than the sexual and gender-based violence that more typically is perpetrated against women and girls. This has resulted in further marginalisation and gender discrimination.

If States are to deliver fully on their human rights obligations, a gender analysis is critical to understanding the lived realities and harms experienced by all persons during armed conflict and its aftermath. Recognising how gender operates and intersects with other axes of discrimination not only reveals how and why CRSV remains an endemic feature of war, but also can help States to provide appropriate responses to violations and importantly craft effective prevention strategies. For these reasons, feminist scholars and women's rights activists have long urged States to ensure that reparations are both gender-sensitive and transformative in ambition. Released in 2007, the Nairobi Declaration on Women's and Girls' Right to a Remedy and Reparation the output of a women's civil society network initiative encapsulates both objectives. 


\section{i. Gender-sensitive reparations}

One of the main objectives of the Nairobi Declaration is to ensure meaningful participation by victims of CRSV in determining the measures and policies intended for their benefit. The Declaration thus calls on States and other relevant bodies to ensure that women and girls are involved in the decision-making process, including in the design of administrative schemes. Building on the Basic Principles, the Nairobi Declaration makes clear that for reparations to be just, adequate and effective, an understanding of the gendered nature and consequences of the harm suffered due to CRSV is required. For example, for restitution to be adequate and effective, victims who cannot return to their own communities because of stigma or ostracism may require being relocated to alternative places of safety where they can rebuild their lives. Gender-sensitive awards of compensation require that any barriers that women and girls face in accessing or keeping money safely must be fully addressed. Likewise, a gender-sensitive approach to rehabilitation must at a minimum provide specialist health services to address the particular harms that women and girls experience including accessing safe abortion services and safe facilities for childbirth. But, whatever form adopted, reparations can only be meaningful with women's participation.

\section{ii. Transformative reparations}

The Nairobi Declaration challenges traditional notions of reparation founded on restitution that seeks to re-establish the situation as it existed prior to the illegality, since to do so would be to restore the gender inequalities that contributed to and made possible the gendered harm in the first place. Instead, the Declaration calls on States to ensure that reparations provide a route through which to address discrimination. The concept of transformative reparation - which is closely linked to the reparative principle of 'guarantees against non-repetition' - is encapsulated in the Nairobi Declaration with the assertion that "reparation must go above and beyond the immediate reasons and consequences of the crimes and violations; they must address structural inequalities that negatively shape women's and girls' lives". In other words, transformative reparations seek to transform gender (and other) relations and social structures founded on inequality, and to unsettle 'patriarchal and sexual hierarchies and customs', thereby reducing the likelihood of repetition.

This requires States to adopt legislation and policies to eliminate all forms of discrimination against women, which is understood to be a root cause of violence. For example, transformative reparations would include legal and social reform across all sectors from education to health services and mandatory gender training for all public officials, not least the judiciary and law enforcement agents. Over recent years, both the Convention Against the Elimination of Discrimination against Women Committee and the Inter-American Court on Human Rights have ordered reparations with transformative impact.

\section{Why are we still here?}

Although criminal prosecutions are an important reparative measure, prosecutions alone cannot address the complex needs of women and girls who have been subjected to CRSV. Moreover, to focus on the perpetrator is to lose sight of the role played by the State. CRSV does not happen in a vacuum. It is rooted in structural and cultural practices founded on discrimination and intersecting inequalities that are aggravated in armed conflict. It is a manifestation of the catastrophic failure by the State to live up to its minimum human rights obligations owed to women and girls. Gender sensitive reparations can begin to address some of the more immediate and pressing needs of survivors. But until States take positive legal and policy measures to counter gender-based discrimination and transform existing gender relations CRSV will continue to destroy the lives of women and girls across the world.

This policy brief was written with the support of a European Research Council (ERC) grant under the European Union's Horizon 2020 research and innovation programme (Grant agreement No. 786494). 
